\title{
15th International Meeting on Chemical Sensors (IMCS15) 報告
}

山口昌樹（岩手大学）

今回の IMCS は, 3 月 16 日から 19 日の 4 日間にわたり， アルゼンチンのブエノスアイレスで開催された。IMCS は， 環境, 工業用途のガスセンサと，健康，医療用途のバイオ センサからなる化学センサの研究者が, 2 年に一度, 一堂に 会して議論を行うことを特徽としている。欧州, 南北米, アジアをほぼ順番に回りながら開催されており，前回のド イツ・ニュルンベルクから, 今回は珍しく南米での開催と なった。

発表件数は, 基調講演 4 件, 口頭発表 89 件，ポスター発 表 163 件であり, 参加者は 230 名ほどと小規模であったが, 参加国はドイツ，フランス，イタリア，スペイン，ロシア をはじめとする欧州全域，日本，韓国，中国などといった アジア諸国, カナダ, アメリカ, そして南米のブラジル, アルゼンチンなど全世界に広がり，真の国際会議といえる ものである。これは, センサの研究が大型で特殊な設備や 計測機器をあまり必要とせず，ユニークなアイデアさえあ れば取り組みやすいテーマであることとも無縁ではなかろ う。今回は, アルゼンチンの公用語がスペイン語というこ ともあり，コーヒーブレークで英語よりもむしろスペイン 語をよく耳にしたような気がし，スペイン語圈の広さも再 認識させられた。また，ガラディナーのタンゴ・ショーは， 世界中の参加者に南米の情熱を伝えたようだ。

3 月は秋にあたるが, 熱くも寒くもなくちょうど良い気温 で, 湿度も低く, 会期中ずっと晴天続きで, 誠に快適であっ た。首都ブエノスアイレスは人口 290 万人ほどの大都会で あるにもかかわらず，人々は非常にゆったりとしていた。 日本では 10 分ほどでできることで 30 分以上待たされるこ ともしばしばで,「ブエノスアイレス時間」というのが流れ ているように感じた。

口頭発表は，3 日間にわたって 4 つのパラレルセッション で行われた。以下は，口頭発表のセッションタイトルであ る。

1. Sensing for Health, Safety and Security

2. Technologies for Chemical and Biochemical Sensing

3. Emerging Sensing Materials and Technologies

4. Chemical and Biochemical Sensors

5. Sensors for High Temperature Processes and Harsh Environment Applications

6. Sensor Arrays and Data Analysis

7. Mechanisms, Modeling and Simulation

発表の半数はガスセンサに関するもので，デバイス作

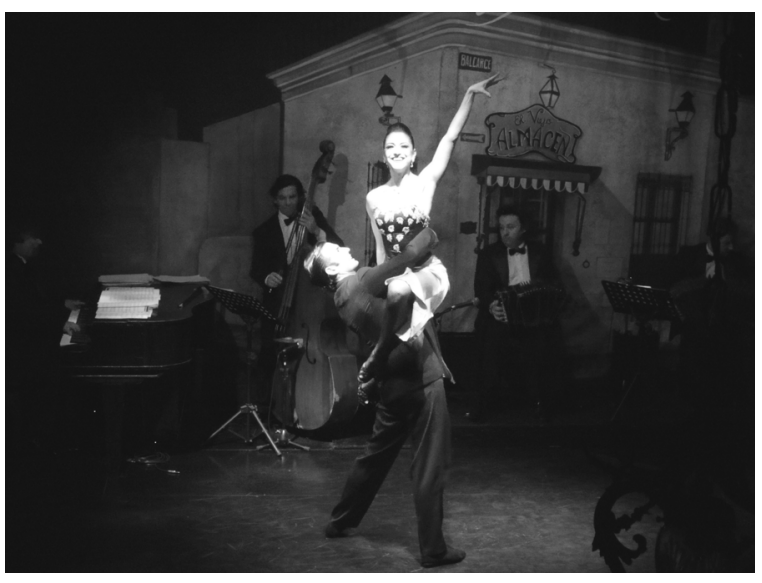

図 1 参加者を楽しませた情熱のタンゴ・ショー

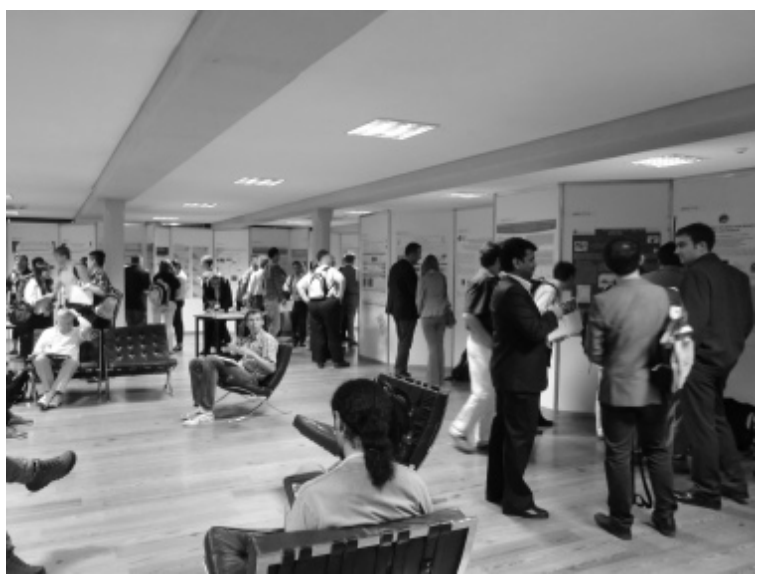

図 2 ポスターセッション会場の様子

製・実装報告と，MEMSによる小型・マルチ化が中心と感 じた。残り半分がイムノアッセイを分子認識手段に用いた バイオセンサであった。こちらも MEMSによる微細流路, 流体弁, サンプル溶液の定量化技術が進んでおり, 将来は, 集積回路のように，化学デバイスで集積流体回路が実現さ れる予感を感じさせた。

また，化学センサの応用は，国情を表していた。資源国 であるアメリカやオーストラリアは水や土中の重金属の監 視センサ, 中国は大気環境のモニタリング, 日本は食品検 査といった具合である。社会への実装を模索するのも, 本 会議の特色であろう。次回は, 2016 年 7 月に韓国の済州島 で開催される予定で，日本人にはぐっと近くなる。

(平成 26 年 5 月 2 日受付) 